\title{
Variasi Morfologi dan Deteksi Leucocytozoon caulleryi dengan Metode PCR pada Ayam Ras di Wilayah Endemis Indonesia
}

\section{Morphological Variation and Detection of Leucocytozoon caulleryi by PCR on Domesticated Chickens (Gallus Sp.) in Endemic Area of Indonesia}

\author{
Endang Suprihati ${ }^{1}$, Wiwik Misaco Yuniarti ${ }^{2}$ \\ ${ }^{1}$ Departemen Parasitologi, ${ }^{2}$ Departemen Klinik Veteriner, Fakultas Kedokteran \\ Hewan, Universitas Airlangga, J1. Mulyorejo, Kampus C, Surabaya, 60115 \\ Email: esuprihati@yahoo.co.id; wiwikmisaco@yahoo.com
}

\begin{abstract}
The purpose of this study was to analyze the variation in morphology and detection Leucocytozoon caulleryi by PCR in mtDNA genes cty $b$ that attacking bred chickens in endemic areas of Indonesia. This study was divided into three stages, data collection of Leucocytozoonosis cases in endemic areas of Indonesia; identification of parasites Leucocytozoon caulleryi morphologically through microscopic examination; and the identification of Leucocytozoon caulleryi cyt $b$ genes that attack bred chickens in endemic areas by PCR. The results showed that there are variations in morphology of Leucocytozoon caulleryi that attacking chicken in endemic areas of Indonesia. Gamete morphometry of L. caulleryi had an average length and width $18.233 \pm 4.672$ dan $12.934 \pm 3.349 \mu \mathrm{m}$. Nested PCR clearly showed positive reaction of Leucocytozoon infections by amplicons in $600 \mathrm{bp}$ and $03 \mathrm{bp}$ length.
\end{abstract}

Key words: Leucocytozoon caulleryi, cyt b gene, domesticated chicken, Indonesia

\begin{abstract}
Abstrak
Tujuan penelitian untuk menganalisis variasi morfologi dan deteksi Leucocytozoon caulleryi dengan metode PCR pada mtDNA gen $c y t b$ yang menyerang ayam ras di wilayah endemis Indonesia. Penelitian ini dibagi dalam tiga tahap, yaitu: koleksi data kejadian kasus Leucocytozoonosis di daerah endemis Indonesia (63 ekor ayam dengan gejala klinis Leucocytozoonosis); identifikasi parasit Leucocytozoon caulleryi secara morfologis melalui pemeriksaan mikroskopis (15 sampel darah positif); dan identifikasi gen cyt b Leucocytozoon caulleryi yang menyerang ayam ras di daerah endemis dengan metode PCR (15 sampel darah positif). Hasil penelitian menunjukkan, bahwa di wilayah endemis Indonesia variasi morfologi Leucocytozoon caulleryi yang menyerang ayam ras memiliki ukuran rata-rata panjang dan lebar 18,233 \pm 4,672 dan 12,934 $\pm 3,349 \mu \mathrm{m}$. Hasil identifikasi Leucocytozoon_caulleryi dengan PCR menunjukkan panjang basa 600 bp pada putaran ke 1 dan 503 bp pada putaran kedua.
\end{abstract}

Kata kunci: Leucocytozoon caulleryi, gen cyt b, ayam ras, Indonesia

\section{Pendahuluan}

Leucocytozoon adalah parasit protozoa darah yang termasuk famili Plasmodiidae yang menyerang unggas. Pada ayam ras, L. caulleryi adalah protozoa yang sangat patogen, ditularkan oleh Culicoides spp., sering terjadi di beberapa negara Asia termasuk Indonesia. Pada industri perunggasan, Leucocytozoonosis pada ayam ras merupakan ancaman serius, selain dapat menyebabkan kematian juga dapat menimbulkan kerugian besar dalam bentuk hambatan pertumbuhan, penurunan berat badan dan penurunan produksi telur. Selain itu, serangan Leucocytozoonosis di daerah endemis selalu muncul sepanjang tahun. Pada ayam pedaging kejadian Leucocytozoonosis tertinggi dijumpai pada umur 2530 hari sebesar 66,67 \% (Isobe et al., 1987; Purwanto, 2009). 
Sejak tahun 2007, kejadian Leucocytozoonosis pada ayam ras muncul di beberapa daerah endemis di Indonesia yaitu Jawa Timur, Jawa Tengah dan Kalimantan Selatan. Pada 2009 sampai pertengahan 2010, kasus Leucocytozoonosis masih sering ditemukan di beberapa wilayah Jawa Tengah dan Jawa Timur. Kejadian Leucocytozoonosis pada ayam ras di Jawa Timur sebesar 32 \%, Jawa Tengah $67 \%$, sedangkan angka kejadian Leucocytozoonosis pada ayam lokal dan burung belum dilaporkan (Purwanto,2009).

Selama ini deteksi terhadap Leucocytozoon pada ayam didasarkan pada analisis morfologi parasit menggunakan mikroskop terhadap hapusan ulas darah. Kelemahan metode ini adalah kegagalan menemukan parasit pada kasus parasitemia yang rendah, apalagi stadium gamet dari parasit ini hanya satu minggu berada di sirkulasi darah (Isobe et al., 1987; Sato et al., 2007). Oleh karena itu perlu dikembangkan metode diagnosis secara molekuler, antara lain dengan metode Polymerase Chain Reaction (PCR) yang selama ini belum dikembangkan di Indonesia untuk deteksi Leucocytozoonosis Darmono dkk., 2006).

Identifikasi morfologi Leucocytozoon spp. tidak dapat digunakan untuk penentuan spesies karena terdapat variasi morfologi, sehingga sering menimbulkan kesulitan dalam mengkarakterisasi morfologi parasit. Penggunaan PCR memungkinkan kita untuk mengetahui perbedaan profil fragmen DNA hasil amplifikasi. Hasilnya bisa kita gunakan untuk membedakan mikroorganisme pada tingkat genus, hingga spesies bahkan genotipe spesifik dari patogen Martinsen, 2006).

Selama ini analisis DNA terhadap Leucocytozoon dilakukan pada gen cyt $b$ (Perkins et al., 2002; Sehgal et al., 2006; Sato et al., 2007). Fragmen gen cyt $b$ merupakan salah satu fragmen yang berada di dalam genom mitokondria dan banyak digunakan untuk mempelajari filogenetik karena variasi susunan nukleotida di dalam gen cyt $b$ sangat berguna untuk membandingkan spesies pada genus ataupun famili yang sama. Rangkaian informasi genetik yang terkandung di dalam DNA mitokondria dilaporkan dapat menggambarkan karakteristik suatu populasi, filogenetik dan merekonstruksi sejarah evolusi (Kvist, 2000).

Penelitian ini dilakukan untuk menganalisis variasi morfologi dan deteksi Leucocytozoon caulleryi dengan metode PCR pada mtDNA gen $c y t b$ yang menyerang ayam ras di wilayah endemis Indonesia.

\section{Materi dan Metode}

\section{Waktu dan Tempat Penelitian}

Pengambilan sampel dilakukan di daerah endemis yaitu: Jawa Timur meliputi Pasuruan, Blitar, Lumajang dan Lamongan. Jawa Tengah meliputi Boyolali dan Purbalingga, serta Kalimantan Selatan di Kecamatan Kurau, Kabupaten Tanah Laut. Pemeriksaan sampel dilaksanakan di Laboratorium Parasitologi dan Laboratorium Biologi Molekuler, Fakultas Kedokteran Hewan, Universitas Airlangga.

\section{Populasi dan Sampel Penelitian}

Ayam ras yang digunakan pada penelitian ini berjumlah 63 ekor ayam yang menunjukkan gejala klinis terinfeksi Leucocytozoonosis. Jumlah tersebut berasal dari daerah Blitar (10 ekor), Lamongan (6 ekor), Pasuruan (10 ekor), Lumajang (4 ekor), Boyolali (10 ekor), Purbalingga (8 ekor) dan Banjarmasin (15 ekor) menggunakan metode purposive sampling. Sampel yang akan dianalisis adalah darah ayam segar yang berasal dari ayam dengan gejala klinis dan patologi anatomi yang mengarah pada infeksi Leucocytozoon. 


\section{Teknik Pengambilan Sampel}

Pengambilan sampel darah dilakukan dengan menggunakan tabung vacutainer yang telah diisi antikoagulan EDTA $10 \%$ melalui vena brachialis sebanyak $1 \mathrm{ml}$. Darah yang diambil sebagian dibuat untuk pembuatan preparat ulas darah dengan pewarnaan Giemsa, sebagian yang lain diekstraksi dengan metode standar fenol kloroform untuk digunakan sebagai sumber DNA genom dan dilanjutkan deteksi DNA Leucocytozoon dengan Nested PCR.

\section{Pemeriksaan parasit melalui preparat ulas darah}

Pemeriksaan ini dilakukan dengan cara melihat parasit dari preparat ulas darah yang telah diwarnai. Ulas darah dibuat setipis mungkin, biarkan mengering kemudian direndam dalam metanol jenuh selama satu menit, selanjutnya direndam dalam larutan Giemsa 20\% selama 20 menit. Tahapan berikutnya preparat disiram dengan air mengalir lalu ditiriskan atau dikeringkan dengan kertas saring. Setelah kering diperiksa di bawah mikroskop dengan perbesaran 1000×; menggunakan mikroskop Olympus BX-50.Pentax optio 230 Camera Digital 2.0 megapixel. Identifikasi parasit dilakukan terhadap panjang dan lebar serta persentase parasit tertutup inti eritrosit, hasil pemeriksaan ini akan menggambarkan bentuk atau morfologi dan ukuran gamet (Martinsen et al., 2006). Gamet diukur berdasarkan panjang, lebar dan lingkaran. Hasil pengukuran di antara sampel akan menggambarkan variasi morfologi gamet di antara sampel dari darah ayam ras.

Variasi morfologi dihitung menggunakan koefisien variasi yang besarnya dihitung dari rasio simpangan baku terhadap nilai rata-rata dari masingmasing variabel yang diukur dikalikan $100 \%$ (Steel dan Torie, 1989 ). Variabel yang diukur adalah panjang, lebar dan lingkaran.

\section{Isolasi Gen cyt b mtDNALeucocytozoon}

Gen cyt b Leucocytozoon di ekstraksi menggunakan metode phenol-chloroform. Gen cyt $b$ mtDNA diisolasi dari darah ayam utuh (whole blood) yang diberi EDTA. Darah ditampung menggunakan tabung vacutainer dari vena brachialis $( \pm 1 \mathrm{ml})$ dengan antikoagulan larutan EDTA $10 \%$. Prosedur ekstraksi DNA darah didasarkan pada metode standar fenol-kloroform dengan modifikasi waktu inkubasi sampel lebih pendek.

Secara ringkas prosedur ekstraksi yang dilakukan adalah mengambil sampel darah sebanyak $200 \mu \mathrm{l}$, kemudian ditambah $200 \mu 1$ larutan penyangga pelisis (lysis buffer), divortex dan disentrifugasi untuk mendapatkan pelet. Selanjutnya, ditambahkan larutan pencuci (rinse buffer) dan dilakukan vortex sampai endapan larut. Kemudian ditambahkan larutan digesti (digestion buffer ), enzim proteinase $\mathrm{K}$ dan RNAse dan diinkubasikan overnight pada suhu $55^{\circ} \mathrm{C}$. Setelah sampel tercerna semua, ditambahkan fenol dan dilakukan vortex atau digunakan rotary mixer agar larutan tercampur sempurna.

Larutan disentrifugasi pada kecepatan 13000 rpm selama 2 menit, kemudian supernatan dipindahkan ke tabung eppendorf baru. Supernatan diberi fenol dan klorofom (1:1), kemudian divortex dan disentrifugasi dengan kecepatan $13000 \mathrm{rpm}$ selama 20 menit. Supernatan diambil dan ditambahkan etanol absolut (100\%) untuk presipitasi DNA, kemudian dilakukan sentrifugasi untuk mengendapkan pelet DNA yang diproleh. Selanjutnya etanol absolut dibuang dan pelet dicuci dengan $70 \%$ etanol. Selanjutnya, pelet diendapkan kembali dengan melakukan sentrifugasi $13000 \mathrm{rpm}$. Ethanol dibuang dengan hati-hati agar pelet DNA tidak ikut terbuang. Material atau pelet DNA yang mengendap dalam tabung dikeringkan dengan bantuan aspirator. Setelah kering, pada pelet DNA ditambahkan larutan TE dan dan disimpan dalam freezer untuk proses selanjutnya. 
Setelah DNA hasil isolasi dimurnikan dan diketahui konsentrasinya, maka dipreservasikan untuk disiapkan sebagai cetakan (template) pada reaksi PCR.

\section{Proses polymerase chain reaction}

Perancangan primer didasarkan pada sekuen yang ada sebelumnya, baik dari data hasil penelitian dalam jurnal maupun data yang terdapat dalam GenBank. Primer gen cyt b yang digunakan sebanyak dua primer untuk PCR putaran pertama dan dua primer untuk PCR putaran kedua. Urutan nukleotida untuk p u t a ra $\quad$ p e r t a m a : $\quad 5^{\prime}$

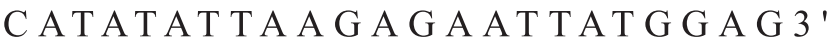
dan5'ATAAAATGGTAAGAAATACCATTC 3'. Sedangkan untuk putaran kedua adalah $5^{\prime}$ ATGTGCTTtAGATATATGCATGCT 3' dan 5'GCATTATCTGGATGTGATAATGGT 3', (Hellgren etal., 2004; Omori etal.,2008).

Amplifikasi mtDNA gen cyt b Leucocytozoon spp. dilakukan dengan menggunakan nested PCR, seperti yang dilakukan oleh Cosgrove et al. (2006). Nested PCR adalah proses amplifikasi DNA yang menggunakan dua pasang primer untuk dua kali PCR. Pada putaran pertama menggunakan primer yang bisa menangkap gen lebih panjang dibanding pada putaran ke dua (Hellgren et al., 2004; Omori et al,. 2008).

Pada putaran pertama, volume total untuk reaksi ini adalah $25 \mu$ l campuran larutan terdiri atas $2 \mu 1$ genomic DNA, 0,125 mM dNTP, 0,2 $\mu \mathrm{M}$ primer, 3
$\mathrm{mM} \mathrm{MgCl} 2$ dan 0,25 unit Taq Polimerase dengan ditambahkan buffer dengan perbandingan 1 kali volume bahan-bahan tersebut. Suhu denaturasi $94^{\circ} \mathrm{C}$ selama 30 detik, suhu annealing $50^{\circ} \mathrm{C}$ selama 30 detik dan suhu perpanjangan (extension) $72^{\circ} \mathrm{C}$ selama 45 detik. Perbanyakan siklus diulang 35 sampai 45 kali.

Bahan-bahan untuk putaran kedua sama dengan putaran pertama, kecuali primer yaitu $0,4 \mu \mathrm{M}$ dan 0,5 unit Taq Polymerase, kemudian 0,2 $\mu$ l dari produk PCR pertama dijadikan template DNA untuk putaran ke dua. Suhu dan waktu di setiap tahapan PCR sama dengan putaran pertama dan perbanyakan siklus sebanyak 20 sampai 35 kali. Dua sampai $8 \mu$ hasil PCR putaran ke dua di running dalam agarose $2 \%$ yang diwarnai dengan ethidium bromide, kemudian divisualisasi menggunakan ultra violet transluminator. Panjang basa yang diharapkan adalah 600 bp pada putaran pertama dan 503 bp pada putaran kedua.

\section{Hasil dan Pembahasan}

\section{Tingkat Kejadian Leucocytozoonosis pada Ayam Ras di Wilayah Endemis Indonesia}

Pengambilan sampel darah ayam ras dilakukan terhadap ayam yang menunjukkan gejala klinis) Leucocytozoonosis di wilayah endemis, meliputi Jawa Timur, Jawa Tengah dan Kalimantan Selatan. Peternakan ayam ras yang mengalami kejadian Leucocytozoonosis bisa dilihat pada Tabel 1

Tabel 1.Tingkat Kejadian Leucocytozoonosis pada Ayam Ras di Wilayah Endemis di Indonesia

\begin{tabular}{ccccc}
\hline No & Lokasi & $\begin{array}{c}\text { Ayam yang nampak } \\
\text { gejala klinis/PA (ekor) }\end{array}$ & Parasitemia (ekor) & $\begin{array}{c}\text { Histopatologis dari yang } \\
\text { parasitaemia (ekor) }\end{array}$ \\
\hline 1 & Blitar & 10 & 2 & 2 \\
2 & Lamongan & 6 & 2 & 2 \\
3 & Pasuruan & 10 & 4 & 4 \\
4 & Lumajang & 4 & 2 & 2 \\
5 & Boyolali & 10 & 1 & 1 \\
6 & Purbalingga & 8 & 2 & 2 \\
7 & Banjarmasin & 15 & 2 & 2 \\
\hline & Total & 63 & 15 & 15 \\
\hline
\end{tabular}


Identifikasi L. caulleryi Secara Mikroskopis

Pemeriksaan Parasitologis

Hasil pemeriksaan ulas darah dengan pewarnaan Giemsa didukung dengan hasil
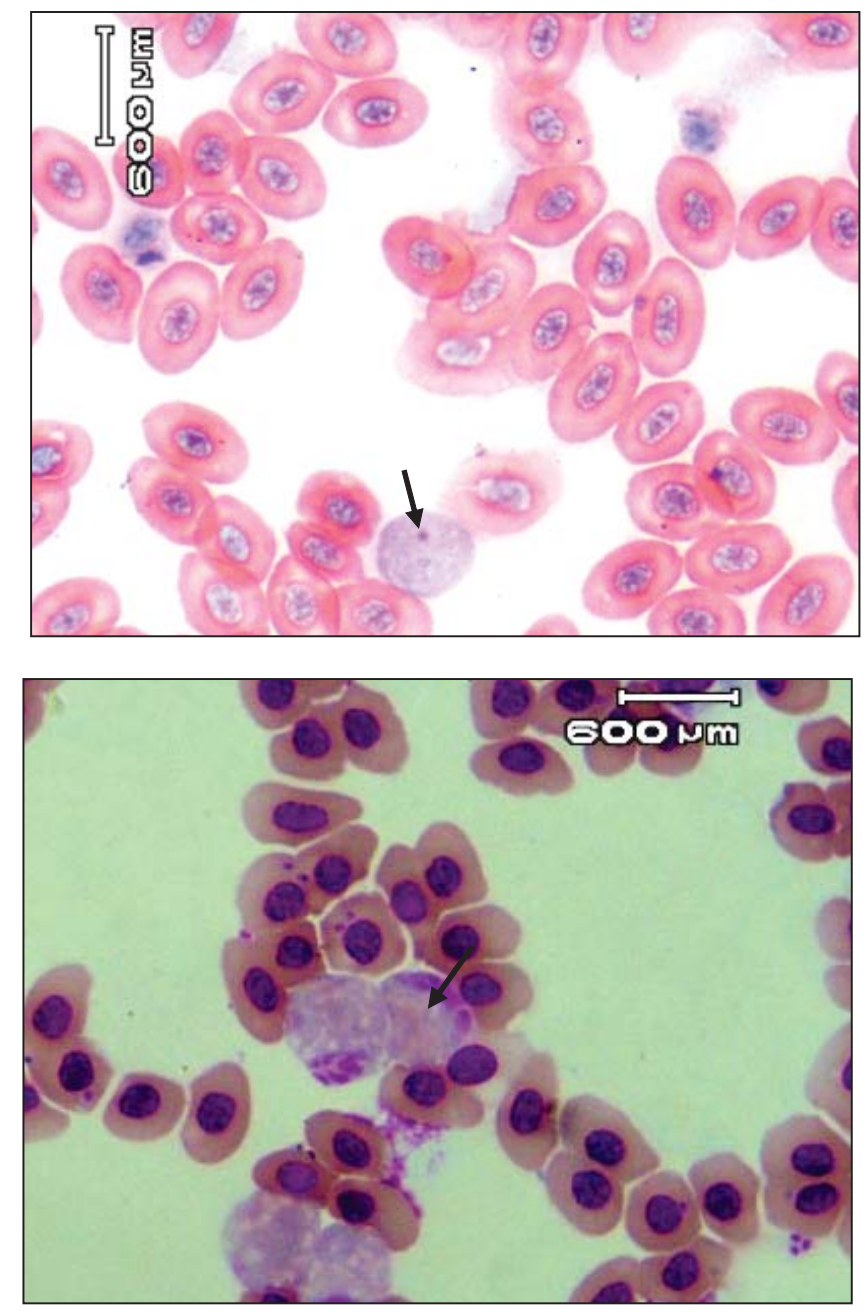

pemeriksaan PCR menunjukkan bahwa Leucocytozoon yang ditemukan dalam penelitian ini seluruhnya adalah $L$. caulleryi, seperti yang terlihat dalam Gambar 1.
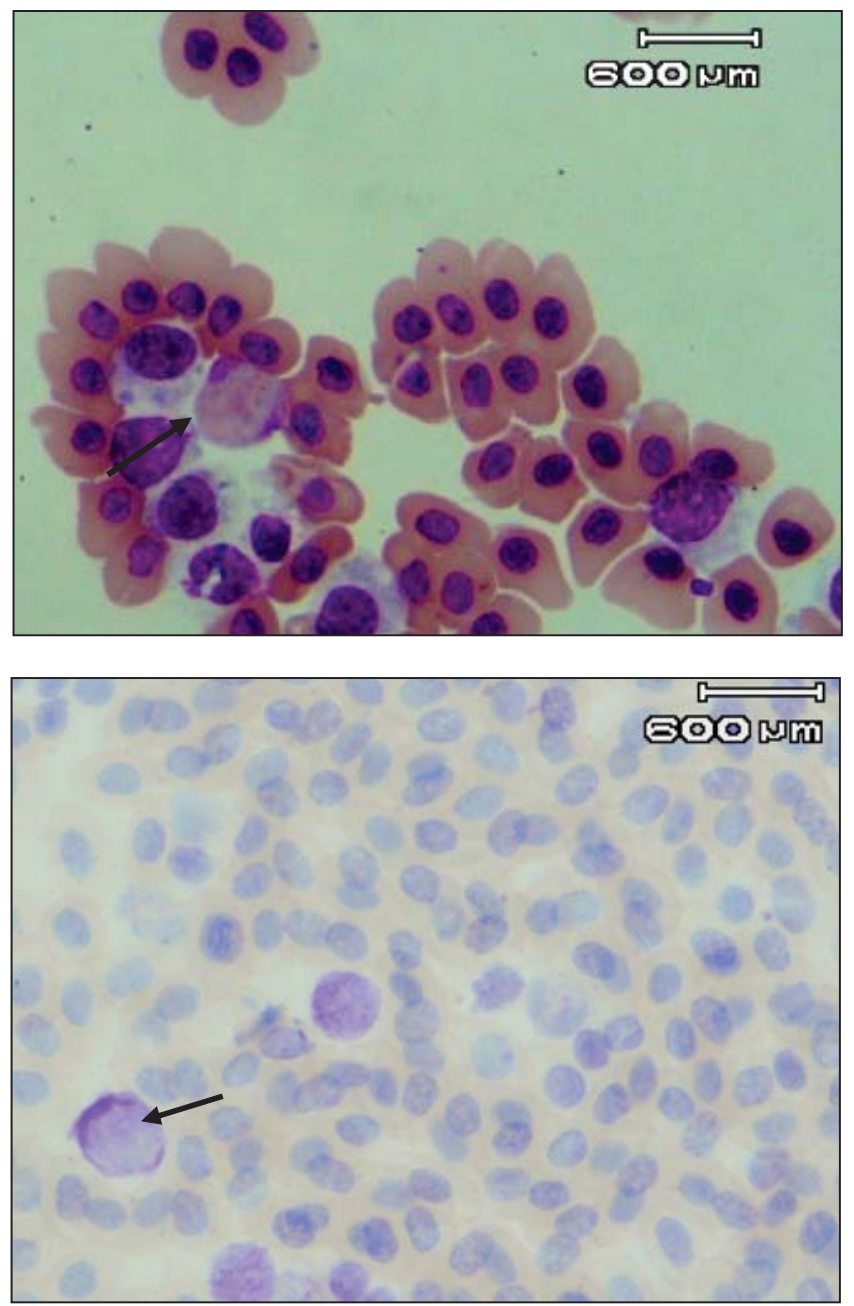

Gambar 1. Leucocytozoon caulleryidari daerah penelitian. $\mathrm{A}=$ L. caulleryi dari Purbalingga 2, $\mathrm{B}=$ L. caulleryi dari Pasuruan 3, C = Pasuruan 4, D = L. caulleryi dari Banjarmasin 1. (Olympus CX-21, 1000x; OptiLab Camera Digital2.0 megapixel).

L. caulleryi yang ditemukan dalam penelitian ini secara umum berbentuk bulat membentuk fusi dengan sel inang, tidak ada proses memanjang dari sitoplasma sel inang seperti yang terjadi pada species lain. Masing-masing parasit dari berbagai daerah endemis ini ada perbedaan fenotipiknya, yaitu ukuran bervariasi: panjang 11,32 - 25,88 $\mu \mathrm{m}$ lebar 9,08 - 21,79 $\mu \mathrm{m}$, dengan rata-rata panjang $18,23 \mu \mathrm{m}$ dan lebar 12,93 $\mu \mathrm{m}$. Koefisien variasi untuk panjang sebesar $25,62 \%$ dan lebar 25,89\% (Tabel 2).
Hasil temuan L. caulleryi dalam penelitian ini secara umum berbentuk bulat dan terdapat variasi morfologi diantara L. caulleryi yang diambil dari berbagai wilayah endemis. Variasi yang terjadi disamping berdasar ukuran, terlihat sitoplasma parasit yang berbeda dalam penyerapan zat warna Giemsa. Menurut Valkiunas et al. (2010), untuk penentuan spesies hal yang paling menentukan adalah bagaimana proses sitoplasma inang dalam mengadakan fusi dengan parasit, masing-masing spesies memiliki 
Tabel 2. Morfometri Gamet L. caulleryi yang Menyerang Ayam Ras dari Berbagai Daerah Endemis di Indonesia

\begin{tabular}{lccc}
\hline Asal sampel & $\begin{array}{c}\text { Panjang } \\
(\mu \mathrm{m})\end{array}$ & $\begin{array}{c}\text { Lebar } \\
(\mu \mathrm{m})\end{array}$ & $\begin{array}{c}\text { Keliling } \\
(\mu \mathrm{m})\end{array}$ \\
\hline Banjarmasin 1 & 16.5 & 11.04 & 44.72 \\
Banjarmasin 2 & 22.05 & 12.84 & 62.08 \\
Blitar & 25.88 & 21.79 & 71.85 \\
Boyolali & 14.26 & 11.26 & 39.09 \\
Lamongan 1 & 18.83 & 12.06 & 47.38 \\
Lamongan 2 & 16.02 & 12.51 & 45.51 \\
Pasuruan 1 & 24 & 15.5 & 60.88 \\
Pasuruan 2 & 17.72 & 13.72 & 46.33 \\
Pasuruan 3 & 13.55 & 10.87 & 37.53 \\
Pasuruan 4 & 11.32 & 10.19 & 35.16 \\
Purbalingga 1 & 11.36 & 9.08 & 36.1 \\
Purbalingga 2 & 25.5 & 9.48 & 59.03 \\
\hline Rata2 & 18.233 & 12.934 & 47.613 \\
\hline SD & 4.672 & 3.349 & 9.441 \\
\hline Koef. variasi (\%) & 25.623 & 25.8934 & 19.829 \\
\hline
\end{tabular}

pertumbuhan fusiform yang bersifat spesifik, dimana sifatnya bisa ditentukan secara genetik, yang kemungkinan besar mencerminkan sejarah evolusinya.

Perbedaan morfologi dapat diakibatkan oleh perbedaan genetik akibat evolusi, hal ini sesuai dengan yang disampaikan Valkiunas et al., (2010). Keragaman Leucocytozoon sangat tinggi, tetapi dapat dibedakan dengan penanda molekuler yangdapat menghasilkan kriteria morfologi baru untuk pengembangan taksonomi spesies parasit haemosporidian. Kriteria seperti itu penting karena identifikasi morphospecies Leucocytozoon saat ini hanya didasarkan pada sifatsifat morfologi sel inang, tetapi tidak pada data parasit secara molekuler.

Kriteria untuk penentuan bahwa spesies tersebut adalah $L$. caulleryi termasuk inangnya dan gambaran gametositnya harus menggunakan beberapa karakteristik seperti pewarnaan, ukuran, sifat, dan tingkat distorsi sel inang, bentuk dan perubahan posisi dari sel inang termasuk dengan intinya (Martinsen et al., 2006). Dalam pemeriksaan darah dari ayam yang menderita Leucocytozoonosis didapatkan gambaran mikroskopis baru berupa protozoa darah yang bercirikan bulat membesar dan berwarna kebiruan.

Berdasarkan analisis morfologi dan morfometri karakteristik gametosit dan sel inang maka Omori et al. (2008) mengusulkan untuk mendeskripsikan dengan jelas $L$. caulleryi dengan kriteria dari morfologi intraspesifik maupun interspesifik dari gametosit serta sel inangnya.Studi yang didasarkan pada pemeriksaan mikroskopis dari pemeriksan ulas darah tipis telah mengungkapkan bahwa ayam terinfeksi parasit darah sering membawa parasit yang berbeda (Valkiūnas, 2005). Namun dalam penelitian ini tidak dijumpai infeksi campuran, hal ini kemungkinan memang tidak didapatkannya agen protozoa darah yang lain. Namun perlu penelitian lebih lanjut dengan jumlah sampel maupun wilayah yang lebih banyak

\section{Identifikasi $L$. caulleryi dengan Penggunaan PCR pada mt DNA Gen cyt b Leucocytozoon}

Hasil penelitian menunjukkan bahwa ayam yang mengalami parasitemia, seluruhnya dinyatakan positif terhadap Leucocytozoon dengan pemeriksaan menggunakan metode nested PCR. Gen cyt $b$ mtDNA berhasil diamplifikasi dengan primer Haem NFI dan Haem NR3 untuk menjaring ketiga genus Haemosporidia yang menyerang ayam dan Haem FL dan Haem R3L, khusus untuk Leucocytozoon (Hellgren, 2004). Dari semua sampel yang diamplifikasi menunjukkan produk PCR dengan spesifikasi tinggi yaitu hanya terbentuk band tunggal dengan panjang nukleotida sekitar 600 bp pada PCR putaran pertama dan 503 bp pada PCR putaran kedua (Gambar 2 dan 3). 


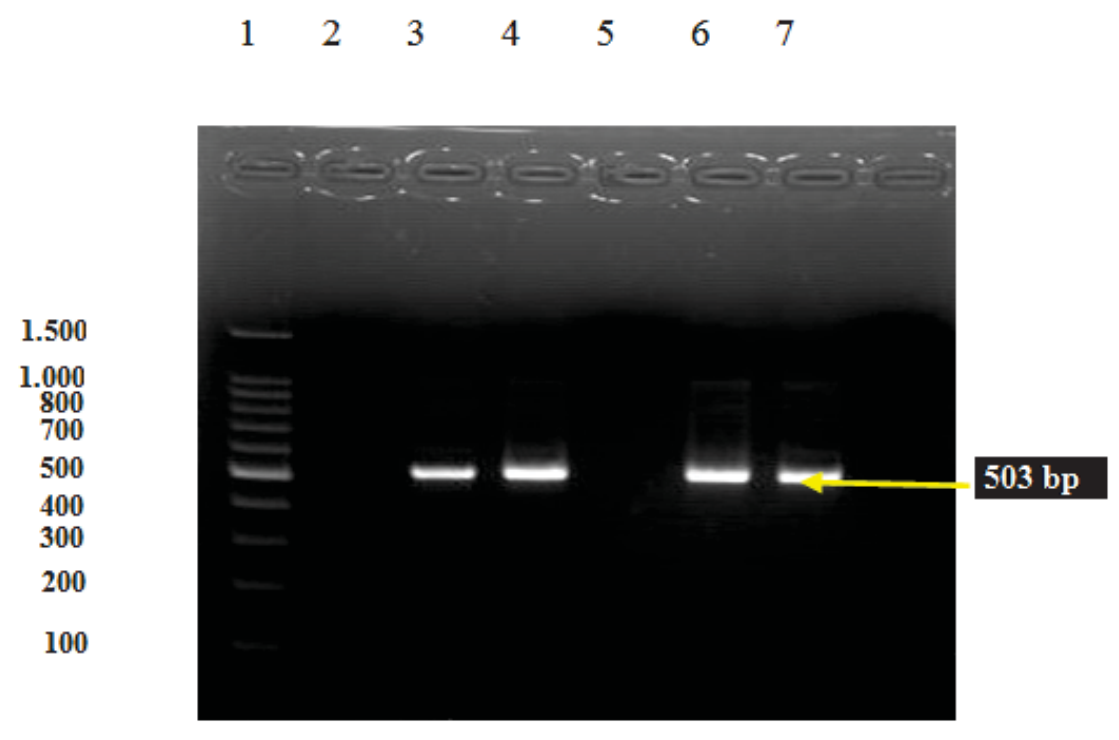

Gambar 2. Gen cyt b 503 bp L. caulleryi pada putaran II. Lajur 1 marker; lajur 2 dan 5 kontrol negatif, lajur 3, 4, 6 dan 7 hasil positif gen $c y t b$ L. caullleryi.

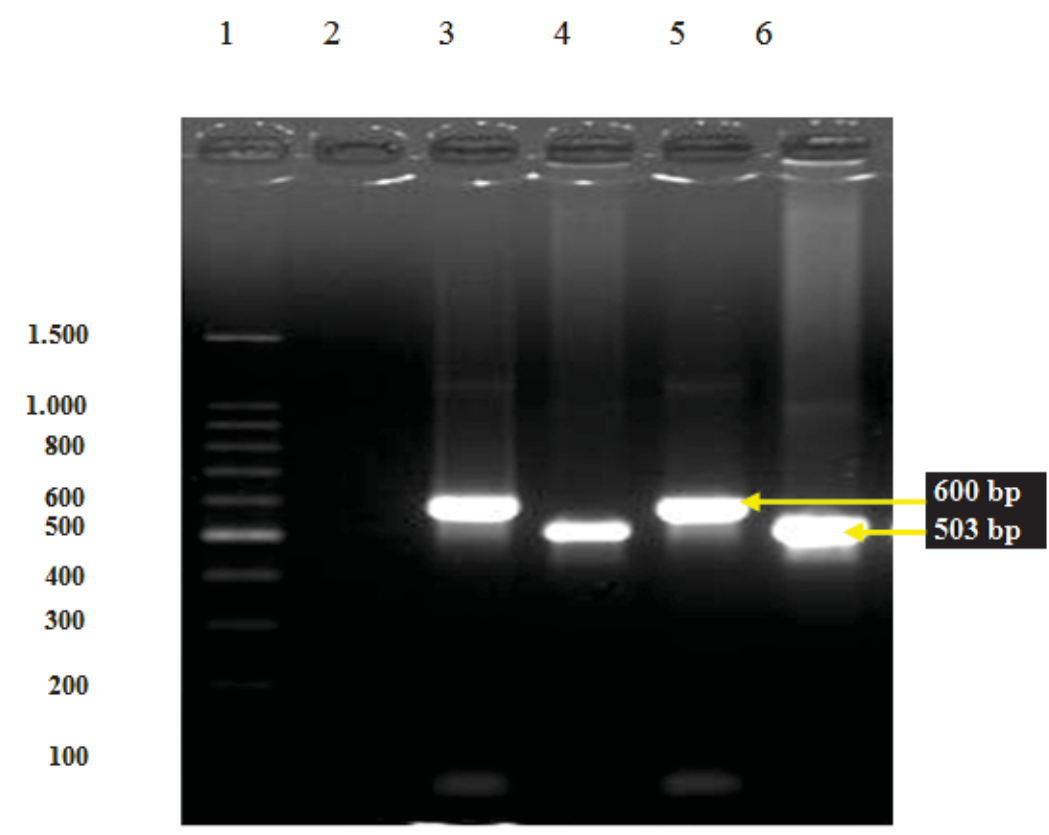

Gambar 3. Gen cyt b 503 bp putaran II dan gen cyt $b 600$ bp putaran I.

Lajur 1 marker; lajur 2 kontrol negatif, lajur 3 dan 5 hasil positif gen cyt b Leucocytozoon putaran I, lajur 4 dan 6 hasil positifgen cyt beucocytozoon putaran II.

Hasil positif parasitemia Leucocytozoon yang menyerang ayam ras di daerah endemis juga menunjukkan hasil positif produk PCR. Hal ini merupakan bukti bahwa PCR dapat diandalkan dalam mendeteksi infeksi Leucozoonosis pada ayam ras. Pendapat ini didukung oleh penelitian tentang parasit malaria khususnya Leucocytozoon pada ayam lokal di Uganda dan Cameroon yang menggabungkan pemeriksaan menggunakan PCR dengan pemeriksaan konvensional. Leucocytozoon pada burung juga dapat dideteksi dengan PCR dengan DNA yang diekstraksi dari darah yang dikoleksi lebih dari 2 tahun sejak 
infeksi yang pertama. Hal ini menunjukkan ketahanan jangka panjang infeksi aktif. Namun, deteksi dengan metode PCR pada stadium skizont belum pernah dilakukan (Cosgrove et al., 2006; Sehgal et al., 2006; Valkiunas et al., 2010).

Nested PCR dipilih pada penelitian ini karena nested PCR menggunakan dua (2) pasang primer. Satu (1) pasang primer yang kedua (nested) berada dalam fragmen primer yang pertama. Hasil PCR dengan primer kedua lebih pendek daripada dengan primer yang pertama dan lebih spesifik. Selain itu, keuntungan lain penggunaan nested PCR adalah meminimalkan kesalahan amplifikasi. Nested PCR memiliki aplikasi yang luas, karena memiliki spesifisitas dan sensitivitas yang tinggi, sehingga hasilnya lebih akurat dibandingkan metode PCR lainnya.

Perkiraan prevalensi parasit berdasarkan ulas darah dan tes PCR mewakili tingkat minimum infeksi, sedangkan perkiraan berdasarkan pemeriksaan serologis dapat mewakili tingkat maksimum infeksi. Hal ini dapat diperoleh dari hasil penelitian semua individu yang pernah terinfeksi (Perkins dan Schall, 2002). Teknik diagnostik baru berupa tes PCR perlu terus dilakukan untuk mengungkapkan prevalensi parasit malaria unggas (2004). Intensitas infeksi dapat dengan mudah terdeteksi pada hapusan darah yang dapat mencerminkan melemahnya sistem kekebalan inang. Namun kasus Leucocytozoonosis memiliki kesulitan tersendiri dalam mendeteksi parasit, karena keberadaan gamet dalam darah hanya 1 minggu. Penggunaan PCR untuk mendeteksi DNA parasit yang diamplifikasi dari parasit utuh, tidak mencerminkan tahap penyakit atau tingkat keparahan infeksi (Cosgroveetal., 2006).

Cytochrom adalah daerah genom mitokondria yang merupakan area yang sangat tidak mudah mengalami mutasi, sehingga lokasi ini sangat baik untuk merancang primer PCR untuk mendeteksi infeksi oleh spesies tertentu (Chasar, 2009).

Metode nested PCR pada putaran pertama bertujuan untuk mendapatkan genom yang panjang yang dapat mewakili tingkat family, yaitu family
Plasmodidae. Sementara putaran kedua (nested) akan mendapatkan genom pada tingkat species (spesifik). Penggunaan PCR juga dapat mendeteksi $L$. caulleryi yang bervariasi hingga perbedaan urutan $12 \%$ dalam gen cytochrom b (Martinsen et al., 2006).

\section{Kesimpulan}

Berdasarkan hasil penelitian, dapat disimpulkan bahwa. Terdapat perbedaan variasi morfologi (bentuk dan ukuran) gamet Leucocytozoon caulleryi yang menyerang ayam ras di daerah endemis di Indonesia. L.cauleryi dapat dideteksi menggunakan PCR dengan panjang basa 600 bp pada putaran pertama dan 503 bp pada putaran kedua.

\section{Ucapan Terima kasih}

Ucapan terimakasih kami sampaikan kepada Bapak Suyud dari PT SHS yang telah membantu dalam pengambilan sampel darah ayam ras yang terkena Leucocytozoonosis di daerah endemis, Bapak Amin dari Institute Tropical Disease (ITD), Universitas Airlangga, yang membantu dalam proses PCR, serta para mahasiswa yang membantu dalam proses penelitian.

\section{Daftar Pustaka}

Aiello, S.E.,(2008). Leucocytozoonosis. Merck Veterinary Manual, $8^{\text {th }}$ Ed. National Publishing, Philadelphia, Pennsilvania. 256

Chasar, A., Loiseau, C., Valkiunas, G., Iezhova, T.,Smith, T.B.,and Sehgal, R.N.M., (2009). Prevalence and diversity patterns of avian blood parasites in degraded African rainforest habitats . Mol. Ecol. 18:4121-4133.

Cosgrove, C.L.,Day, K.P., and Sheldon, B.C., (2006). Coamplification of Leucocytozoon by PCR diagnostic test for avian malaria : A cautionary note. J. Parasitol. 92: 1362-1365.

Darmono, T.W., Jamil, I., and Santosa, D.A., (2006). Pengembangan penanda molekuler untuk deteksi Phylophthori palmivora pada tanaman kakao. Menara Perkebunan.74: 87-96.

Hellgren, O.J.,Waldenstrom,J., and Bensch, S.,(2004).A new PCR assay for simultaneous studies of Leucocytozoon, Plasmodium, and 
Haemoproteus from avian blood. J. Parasitol. 90: 797-802.

Isobe, T., and Suzuki, K., (1987). Detection of Serum Antibody to Leucocytozoon caulleryi in Naturally Infected Chickens by ELISA. $J$. of Vet. Med. Sci., 49: 165-167.

Kvist, L., (2000). Phylogeny and Phylogeography of European Parids. Departement of Biology, Oulu University.

Martinsen, E.S., Paperna, I., and Schall, J.J., (2006). Morphological versus molecular identification of avian Haemosporidia: an exploration of three species concepts. Parasitol., 133:279-288.

Morii, T.,andFukuda, M., (2005). Observations on First-Generation Schizogony of Leucocytozoon caulleryi in Chickens. J. of Euk. Microbiol., 39:281-287.

Omori, S.,Sato, Y., Hirakawa, S.,Isobe, T., Yukawa, M., and Murata, K.,(2008). Two extra chromosomal genomes of Leucocytozoon caulleryi:completenucleotide sequences of the mitochondrial genome and existence of the a picoplast genome.Parasitol. Res.,103:953-957.

Perkins, S.L., and Schall, J.J., (2002). A molecular phylogeny of malarial parasites recoverd form ccytochrome b gene sequences. J.Parasitol.,88: 972-978.

Purwanto, B., (2009). Kalau ayam kena Malaria, Majalah Trobos, Edisi Juli.

Sato, Y.,Hagahira, M., Yamaguchi, T., Yukawa, M., and Murata, K., (2007). Phylogenetic Comparison of Leucocytozoon spp from Wild Birds of Japan. J. of Vet.Med.Sci., 69:55-59.
Steel, RG.D.I and Toorie, 2.H (1987) Priciple and Procedures of Statistics. A Biometrical Approach. Mc. Graw Hill Book Co., New York.

Sutarno, J. A., Purwoko, A, dan Lelana, N.I. (2002). Identifikasi dan karakterisasi polimorfisme gen hormone pertumbuhan pada sapi Bali, sapi Madura dan sapi Benggala. Biodiversitas 3: 169-173.

Waldenstrom, J., Bensch, S., Hasselquist, D., and Ostman, O. (2004). A new nested polymerase chain reaction methode very efficient in detecting Plasmodium and Haemoproteus infection from avian blood. J. Parasitol. 90: 191-194.

Valkiunas, G. 2005. Avian malaria parasites and other haemosporidia. CRC Press, Boca Raton, Florida, $946 \mathrm{p}$.

Wardhana, A.H. (2004). Keragaman genetic populasi lalat Myiasis Chrysomyabezziana di Indonesia berdasarkan analisis DNA mitokondria. JITV, 9: $108-114$.

Sehgala., R.N.M., Valkiunas, G., Iezhova, T.A., and Smith, T.B. (2006). Blood parasites of chickens in Uganda and Cameroon with molecular descriptions of Lucocytozoon schoutedeni and Trypanosoma gallinaru. J. Parasitol. 92: 1336-1343. 